Review

\title{
Parasite-host interaction in malaria: genetic clues and copy number variation
}

Imad Faik, Elisandra Grangeiro de Carvalho and Jürgen FJ Kun

Address: Institute for Tropical Medicine, University Tübingen, Wilhelmstr. 27, 72074 Tübingen, Germany.

Correspondence: Jürgen FJ Kun. Email: juergen.kun@uni-tuebingen.de

\begin{abstract}
In humans, infections contribute highly to mortality and morbidity rates worldwide. Malaria tropica is one of the major infectious diseases globally and is caused by the protozoan parasite Plasmodium falciparum. Plasmodia have accompanied human beings since the emergence of humankind. Due to its pathogenicity, malaria is a powerful selective force on the human genome. Genetic epidemiology approaches such as family and twin studies, candidate gene studies, and disease-association studies have identified a number of genes that mediate relative protection against the severest forms of the disease. New molecular approaches, including genome-wide association studies, have recently been performed to expand our knowledge on the functional effect of human variation in malaria. For the future, a systematic determination of gene-dosage effects and expression profiles of protective genes might unveil the functional impact of structural alterations in these genes on either side of the host-parasite interaction.
\end{abstract}

\section{Introduction}

Malaria is a disease caused by Apicomplexa parasites of the genus Plasmodium, and is transmitted by the bite of an infected female Anopheles mosquito. Malaria has affected humans since their evolutionary emergence as a separate species. The divergence of man and chimpanzee is paralleled by the divergence of the two specific parasites Plasmodium reichenowi and Plasmodium falciparum [1].

The earliest references to malaria are descriptions of splenomegaly with fever from China in the Nei Ching Canon of Medicine in $1700 \mathrm{BC}$, and from Ancient Egypt in the Ebers Papyrus in 1570 BC. The parasite was identified by Alphonse Laveran in 1880; Giovanni B Grassi and Sir Roland Ross demonstrated that malaria parasites could be transmitted to infected vertebrate hosts (birds and humans) by mosquitoes.

Malaria is one of the main global causes of death from infectious diseases, which are one of the major public health issues, especially in developing countries. In the year 2001, about 14.5 million deaths were attributed to the effects of infectious diseases. About 40\% of the world population is at risk for malaria, causing around 1 million deaths each year, predominantly in infants [2].

Malaria is a devastating disease that not only has an effect on the health system, but also slows the rate of long-term economic growth and development. Global climate change and a possible further migration of parasites will put even more people at risk in the future.

Malaria has a broad distribution in both subtropical and tropical regions, with many areas of the tropics being endemic for the disease. The countries of sub-Saharan Africa carry the highest burden of all malaria cases. In many temperate and richer areas, such as Europe and the USA, public health measures, economic development and environmental changes have successfully eliminated the disease, apart from a minor number of cases imported by travelers.

The life cycle of all Plasmodia species is very similar and follows basically the same process (Figure 1). Development involves a host change from an arthropod vector to a vertebrate host (the female Anopheles mosquito and the human host for Plasmodia), with a mostly intracellular life style. Infection is initiated with the bite of an infected female Anopheles mosquito and the injection of sporozoites from the salivary glands into the host's bloodstream (Figure 1a). Within minutes, the sporozoites invade hepatocytes (Figure 1b) and undergo an asexual replication that results in the production of schizonts. The hepatocytes burst (Figure 1c) after five days at the earliest, and release merozoites into the bloodstream (Figure 1d). The released merozoites then invade red blood cells (RBCs) and initiate another asexual replication phase in the erythrocyte.

$A D R$, adrenoceptor; CNV, copy number variation; CQ, chloroquine; CR1, complement receptor 1; CYP2A6, cytochrome pigment 450; dhfr, dihydrofolate reductase; FcyR, receptor for the constant fragment of immunoglobulin G; FCGR, gene for the constant fragment of immunoglobulin G; FCGR2A/3B, receptor for the constant fragment of immunoglobulin G, low affinity Ila/lllb; gch1, GTP-cyclohydrolase 1; GWAS, genome-wide association studies; GPC, glycophorin C; HLA, human leukocyte antigen; ICAM-1, intercellular adhesion molecule 1; IL, interleukin; MBL2, mannose/mannan-binding lectin2; Pfcrt, Plasmodium falciparum chloroquine resistance transporter; Pfmdr, Plasmodium falciparum multi-drug resistance; RBC, red blood cell; SNP, single nucleotide polymorphism. 


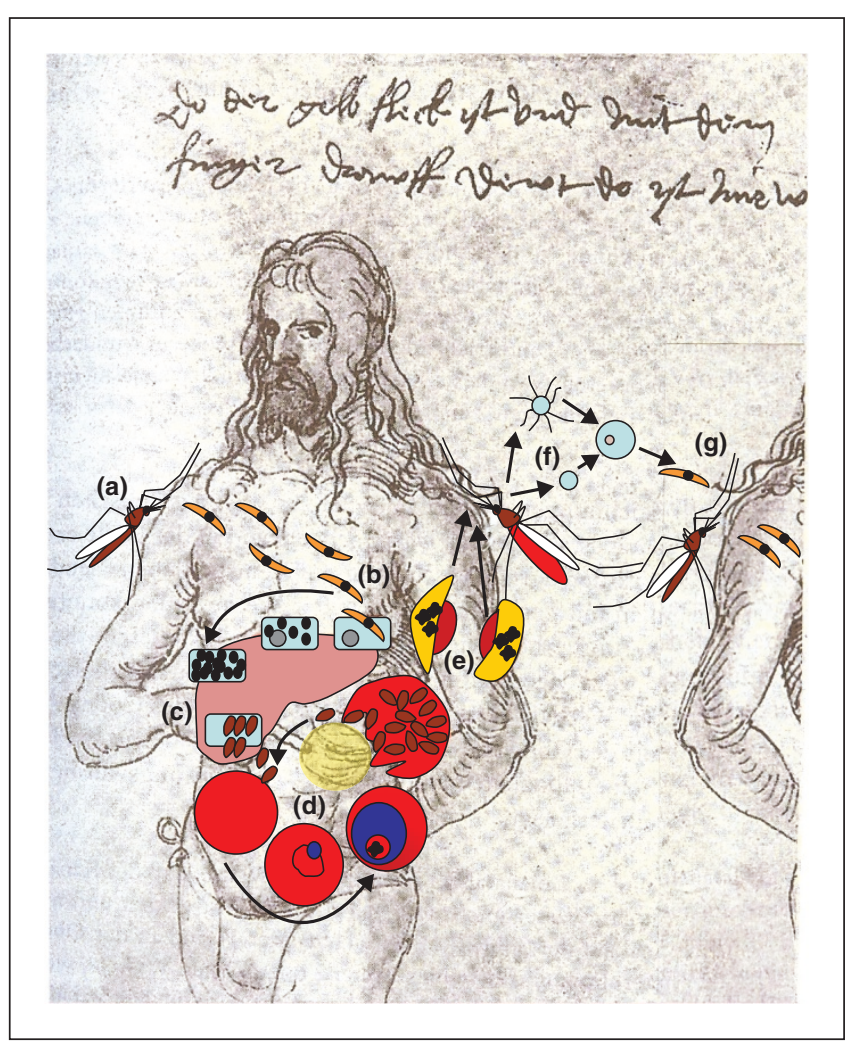

Figure 1

Life cycle of Plasmodium falciparum (a-g) projected onto a sketch drawn by the German Renaissance painter Albrecht Dürer (1471-1528). This sketch was drawn by Dürer for his doctor pointing to the site of nagging pain, presumably due to splenomegaly. Dürer supposedly contracted malaria on a trip to The Netherlands, never recovered completely and died of it 13 years later.

Invaded merozoites develop from the trophozoite to the schizont containing 16 to 32 new merozoites. These are released and re-invade new RBCs. The duration of the cycle is species dependent and can vary between 24 hours (P. knowlesi) and 72 hours (P. malariae). Alternatively, some parasites differentiate within the RBC into the sexual forms, the male and female gametocytes, which are taken up by a female mosquito (Figure 1e). Within the mosquito mid-gut, the male gametocyte undergoes a nuclear division, producing eight flagellated microgametes that will fertilize the female macrogamete (Figure 1f). At the end of the zygote development, hundreds of sporozoites are formed, which migrate to the mosquito salivary gland awaiting injection into the human host (Figure 1g).

The clinical spectrum of malaria is wide, spanning from asymptomatic infections, fever and mild anemia, to severe anemia and cerebral malaria and, subsequently, death [3]. Until recently, four distinct species were recognized as human pathogens: $P$. falciparum, $P$. vivax, $P$. malariae, and $P$. ovale, with $P$. falciparum the most lethal, causing the majority of deaths. Very few fatalities are caused by $P$. vivax, and no deaths have been reported by the latter two so far. A fifth parasite, $P$. knowlesi, known as a simian parasite, is now also considered to be pathogenic for humans [4].

\section{The influence of host and parasite genetics in malaria \\ Malaria and single nucleotide polymorphisms}

In humans, a genetic contribution to resistance against malaria has long been suspected, and epidemiological evidence exists for the protective sickle cell trait in malaria [5]. It is estimated that genetic factors account for approximately one-quarter of the total variability in malaria incidence of a study population, with the hemoglobin $\mathrm{S}$ gene explaining $2 \%$ [6]. This finding indicates the influence of many other unexplored protective genes, each individually resulting in small population effects.

Genetic markers such as single nucleotide polymorphisms (SNPs) are a valuable tool to study risk assessment and progression of infectious diseases. SNPs are highly frequent and are abundant in the human genome [7]. SNPs that lead to amino acid changes are of particular importance, providing an indication of how the protection is mediated.

It is obvious that parasitic and human receptor-ligand interaction is involved in the parasite's various invasion processes into erythrocytes or liver cells. This interplay of two organisms has to be balanced carefully to ensure the survival of both. This balance is reflected in genetic alterations in both the host and the parasites.

\section{Genetic variation in response to malaria}

Epidemiological studies of malaria in humans have demonstrated that malaria phenotypes, including severity, disease incidence and parasitemia, can significantly vary amongst individuals [8]. In 1997, a longitudinal study of malaria in sibling pairs was designed to investigate the extent of the genetic determinants of predisposition to clinical malaria in rural Gambia [9]. In this study, a strong association of human leukocyte antigen (HLA) genes was found to contribute to the risk of contracting uncomplicated malaria. In 2000, a quantifying analysis of the implication of genetic and non-genetic factors in malarial infection was conducted in a rural Sri Lankan population [10]; the heritability was estimated to be around $10 \%$ for the intensity of the clinical signs and about $15 \%$ for the incidence of asymptomatic and symptomatic $P$. falciparum infections. A strong association of age with potential genetic determinants was also detected, whereas the extent of the genetic effect was higher in infants in comparison with adults [11]. Genetic epidemiological studies using segregation analyses in a sib-pair linkage analysis identified genetic factors that were linked to the level of malarial infection in Burkina Faso [12]. This analysis 
focused on the chromosomal region 5q31-33 and suggested that the genes coding for $\beta_{2}$-adrenergic receptor (ADR) and the interleukin genes (IL)-9 and -13 are involved in the control of the infection. Many immunological studies have investigated the genetic regulation of the variation of human immune responses to malaria. In the early 1990s, one of the leading studies was conducted in twin pairs from Liberia and Madagascar, measuring antibody levels to malaria antigens [13]. A high analogy in antibody levels was detected in monozygotic twins compared with dizygotic twins or sex- and age-matched siblings, and unrelated individuals under similar exposure to malaria transmission. In the following sections, we will describe some of the most important genetic alterations that have an impact on malaria.

\section{Single nucleotide polymorphisms and malaria}

Countless association studies have been performed with numerous SNPs in cohorts of different geographic origin looking at differing disease presentations. Many of these studies have reported conflicting associations or genetic alterations that cannot be explained by malaria exposure

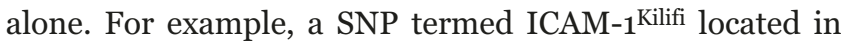
the gene for the intercellular adhesion molecule 1 (ICAM-1) was found to result in an amino acid change at position 29 (Lys to Met). This highly frequent alteration has been associated with a predisposition to cerebral malaria in Kenya [14]. On the contrary, in a case-control study of Gabonese infants, ICAM-1 ${ }^{\text {Kilifi }}$ was associated with protection against severe malaria [15]. The largest study conduc-

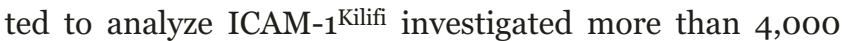
individuals, and no association with any malaria phenotype was observed [16].

An interesting phenotype that has been associated with severity of plasmodial infections is so-called rosetting, by which a parasitized erythrocyte surrounds itself with uninfected red blood cells with the involvement of complement receptor 1 (CR1) [17-19]. Other studies have, however, failed to support the association of disease severity with rosetting [20,21]; on the other hand, results from a study in a Papua New Guinean population have shown that polymorphisms leading to CR1 deficiency mediate protection against severe malaria [22].

Interestingly, reduced rosetting may also play a role in the weakly protective role of blood group o. In African regions with a strong overlap of malaria endemicity and high prevalence of blood group o, it has been reported that this blood group forms rosettes very inefficiently compared to other blood groups [23]. Evidently, in indigenous South American populations with $100 \%$ of the people being 0 positive, other mechanisms must be in action.

In Papua New Guinea, the erythrocytes of a high proportion of the population do not carry glycophorin C (GPC), the component that forms the Gerbich blood type [24]. Malaria parasites use GPC to invade erythrocytes [25]; whether this deficiency has positive effects on malaria outcomes remains to be elucidated .

Mannose-binding lectin (MBL) is a collagen-like serum protein that acts as an unspecific antibody binding to the carbohydrate moieties of pathogens in order to enable macrophages to opsonize them [26]. Common genetic variants located in the human $M B L 2$ gene locus impact the stability and the serum level of the resulting protein, which influences the predisposition and clinical outcome of various infectious diseases of bacterial and parasitic origin [27,28]. A comparison of MBL plasma levels in young Gabonese patients suffering severe and mild malaria suggested a protective effect for MBL [29]. Genetic variants causing lower concentrations of the protein were associated with different malaria phenotypes [30,31]. The effect of MBL on malaria may be explained by a direct binding of MBL to glycoproteins of the merozoites or the infected erythrocyte, as shown by enrichment of parasite proteins on MBL affinity columns [28,32]. Other studies, however, have not shown any association with malaria [33].

\section{Moving from candidate gene studies to genome-wide association studies}

The sequencing of the human genome has generated largescale genomic data, and the HapMap project has identified millions of SNPs, allowing the performance of genomewide association studies (GWASs) [34]. The first investigations of multifactorial infectious diseases utilizing a genomewide technology were conducted in African tuberculosis patients [35] and in Brazilian patients suffering from schistosomiasis [36]. In 2007, a GWAS approach was used to identify the major determinants for host control of HIV [37]. In malaria research, two studies have been performed so far: the first on mild malaria in Ghanaian children [38] and a second on a Gambian cohort with severe malaria [39]. Both studies failed to detect known protective traits, probably due to technical reasons. On the other hand, it is likely that there is not just one protective trait; malariaaffected humans may have many ways of coping with infection. The mechanisms by which one population battles disease may not necessarily be the same as those in a different population. It is probably a feature of complex diseases that they provoke complex weaponry.

\section{Copy number variations in malaria}

One approach that has not been tried so far in malaria research is the determination of copy number variation (CNV) and its possible association with the disease. These structural variations are defined as two-fold or more multiplications of DNA segments larger than $1 \mathrm{~kb}$ [40]. It has become widely accepted that genomic structural alterations, rather than DNA single nucleotide substitutions, account for a significant amount of human genetic 
variation [41]. CNVs between unrelated people can reach $0.4 \%$ of the genome [42]. In an initial CNV study in the human genome, a large number of CNVs was found in immunorelevant genes, some of which are also candidate genes for malaria protection, such as the genes for the receptor for the constant fragment of immunoglobulin $\mathrm{G}$ $(F C G R)$ - important regulators of the immune response and the human leukocyte antigens (HLA) [43]. The association of genetic polymorphisms in the low-affinity receptors IIa and IIIb (FCGR2A, FCGR3B), which encode the $\mathrm{F} c \gamma \mathrm{R}$ molecules, with susceptibility to cerebral malaria is well known [44].

Various studies link the human genetic variations of the $H L A$ genes, whose protein products are responsible for antigen presentation to the immune system, to disease progression and outcome. The first evidence for an association between $H L A$ genetic variants and predisposition to malaria was identified in Sardinians about 25 years ago, when the frequency of $H L A$ alleles was observed to be variable in villages located at different altitudes of the island, indicating an influence of malaria transmission intensity as selective pressure [45]. Independent protective effects against severe malaria in the HLA locus were found in a West African population [46]. Protective genetic variants of $H L A$ were highly prevalent in Africans but rare in other populations, which points to malaria as a creating force. As a result, the functionality of the HLA immune component has been the focus of various studies aiming to develop an HLA subunit vaccine.

\section{Copy number variation in malaria treatment}

Interestingly, treatment of malaria may also be influenced by CNV $[47,48]$. The cytochrome pigment 450 (CYP) $2 \mathrm{~A} 6$ of the P450 family is involved in the metabolism of the newly recommended drug artesunate and present in the genome as multiple copies. Increase in CYP2A6 copy number is also associated with a higher plasma level of the nicotine detoxification product cotinine. Whether individuals with multiple copies also metabolize artesunate more quickly will be the subject of future investigation.

Gene duplications also help the parasite to cope with the unfriendly environment of a chemotherapy-treated patient. Studies in the mechanisms of artemisinin resistance show that drug resistance is conferred by an increased number of gene copies of the multi-drug resistance ( $p f m d r$ ) gene 1 [49-51]. A decrease of copy numbers results in susceptibility to drugs like mefloquine, lumefantrine, halofantrine, quinine and artemisinin [52].

A systematic analysis of the parasite's genome revealed a number of genes in multiple copies [53]. One of them, GTP-cyclohydrolase I (gch1), is situated in a pathway targeted by drugs, but had not previously been identified as mediating resistance to antifolate drugs. Amplification of $g$ ch 1 was also detected in a separate study looking at geographically distinct parasites with known drug resistance profiles [54]. The genomic amplification in gch1 resulted in an increased expression level of the corresponding mRNA. It was also shown that the presence of multiple copies of the gene was associated with mutations in the gene for dihydrofolate reductase (dhfr), which had been identified as the only cause of antifolate resistance. Amplification of gch 1 may be vital to compensate for the putatively fitness-reducing mutations in $d h f r$.

The long-suspected role of $p f m d r$ amplification in chloroquine (CQ) resistance may also be a result of compensation [55]. Later on, it became obvious that pfindr could not be held accountable for all the phenomena of CQ resistance. Finally, the $P$. falciparum chloroquine resistance transporter gene ( $p f c r t$ ) was identified, and mutations mediating resistance were characterized and confirmed clinically $[56,57]$. Several years later, it was shown that parasites with point mutations in pfcrt also multiply the pfimdr gene in vitro, in comparison to their isogenic 'sister' parasites [58].

Duplications exist in other genes responsible for cell division, cell-cycle regulation and sexual differentiation; others remain un-annotated [59]. A very interesting duplication affects the surfins, molecules possibly involved in invasion [6o]. The surfins represent a family of ten members; the relevant gene product of the duplicated surfin is localized on the surface of merozoites $[60,61]$. Multiplication of this gene may lead to the birth of new family members awaiting selectable mutations to evade immune responses or to explore novel invasion pathways. CNV could be the starting point of a new round in the arms race between parasites and the human immune system.

\section{Conclusions}

CNVs are a feature of the parasite-host interaction in malaria. Whereas the parasite perspective of malaria has been under intense investigation, especially regarding drug response and resistance, the host side has so far received less attention. The study of CNVs in relation to malaria could explain some of the discrepancies between genetic association studies, since some of the candidate genes identified do occur as multiple copies.

Knowledge of the role of $\mathrm{CNV}$ in malaria could have three major impacts: the most important feature is to monitor changes in $\mathrm{CNV}$ in the parasite population to recognize emerging drug resistance quickly and early. Drug resistance is one of the biggest problems in battling malaria, and even the newest therapies with artemisinin derivatives are under threat by resistant parasites $[62,63]$. Investigating CNVs of drug-metabolizing P450 may lead to personalized adjustment of drug dosage to compensate for increased degradation of drugs if a surplus of copies is present. 
On the other hand, if a reduced copy number or a SNP with a strong influence on malaria suppresses expression of a protective gene product, one could consider replacement therapy. As has been done for hemophilia patients with factor VIII replacement for decades, infectious diseases like malaria may in the future be treated using protective serum factors such as MBL2 [64] or components of cytokine pathways that are not sufficiently expressed [65].

A joint analysis of CNVs, SNPs and transcriptomics may shed light on the genetics of host-parasite interaction during malaria pathogenesis. Combined with the individual genome sequences [66], 'personalized' genetic analysis (personomics) will give a clear answer to the question of which SNP or CNV influences gene expression in a particular person and how this particular person deals with malaria.

\section{Competing interests}

The authors declare that they have no competing interests.

\section{Authors' contributions}

IF wrote the sections on SNPs and malaria and the GWAS studies and human CNV studies; EGC wrote the historic remarks and the description of the parasite cycle, and JK contributed the parasite-host relationship and parasite $\mathrm{CNV}$ studies, conclusions and final editing.

\section{Acknowledgements}

We are grateful to all researchers who provided the excellent data we used to write this review. We also would like to thank the staff of the Institute for Tropical Medicine for giving us the time to sit down and compile this report.

\section{References}

1. Ollomo B, Durand P, Prugnolle F, Douzery E, Arnathau C, Nkoghe $D$, Leroy $E$, Renaud $F$ : A new malaria agent in African hominids. PLoS Pathog 2009, 5:e1000446.

2. World Health Organization. The World Health Report. Geneva: World Health Organization; 1999-2004.

3. Sachs J, Malaney P: The economic and social burden of malaria. Nature 2002, 415:680-685.

4. Singh B, Kim SL, Matusop A, Radhakrishnan A, Shamsul SS, Cox-Singh J, Thomas A, Conway DJ: A large focus of naturally acquired Plasmodium knowlesi infections in human beings. Lancet 2004, 363:1017-1024.

5. Serjeant GR. Sickle Cell Disease. Oxford: Oxford Medical Publications, 1992.

6. Mackinnon MJ, Mwangi TW, Snow RW, Marsh K, Williams TN: Heritability of malaria in Africa. PLoS Med 2005, 2:e340.

7. Salisbury BA, Pungliya M, Choi JY, Jiang R, Sun XJ, Stephens JC: SNP and haplotype variation in the human genome. Mutat Res 2003, 526:53-61.

8. Greenwood BM, Marsh K, Snow RW: Why do some African children develop severe malaria? Parasitol Today 1991, 7: 277-281.

9. Jepson A, Sisay-Joof F, Banya W, Hassan-King M, Frodsham $A$, Bennett S, Hill AV, Whittle $H$ : Genetic linkage of mild malaria to the major histocompatibility complex in Gambian children: study of affected sibling pairs. BMJ 1997, 315:96-97.

10. Mackinnon MJ, Gunawardena DM, Rajakaruna J, Weerasingha $\mathrm{S}$, Mendis KN, Carter R: Quantifying genetic and nongenetic contributions to malarial infection in a Sri Lankan population. Proc Natl Acad Sci U S A 2000, 97:12661-12666.

11. Garcia A, Marquet S, Bucheton B, Hillaire D, Cot M, Fievet N, Dessein AJ, Abel L: Linkage analysis of blood Plasmodium falciparum levels: interest of the 5q31-q33 chromosome region. Am J Trop Med Hyg 1998, 58:705-709.

12. Rihet $\mathrm{P}$, Traore $\mathrm{Y}$, Abel L, Aucan C, Traore LT, Fumoux F: Malaria in humans: Plasmodium falciparum blood infection levels are linked to chromosome 5q31-q33. Am J Hum Genet 1998, 63:498-505.

13. Sjoberg K, Lepers JP, Raharimalala L, Larsson A, Olerup $O$, Marbiah NT, Troye-Blomberg M, Perlmann P: Genetic regulation of human anti-malarial antibodies in twins. Proc Natl Acad Sci U S A 1992, 89:2101-2104.

14. Fernandez-Reyes D, Craig AG, Kyes SA, Peshu N, Snow RW, Berendt AR, Marsh K, Newbold $\mathrm{Cl}$ : A high frequency African coding polymorphism in the N-terminal domain of ICAM-1 predisposing to cerebral malaria in Kenya. Hum Mol Genet 1997, 6:1357-1360.

15. Kun JFJ, Klabunde J, Lell B, Luckner D, Alpers M, May J, Meyer CG, Kremsner PG: Association of the Icam-1 Kilifi mutation with protection against severe malaria in Lambaréné, Gabon. Am J Trop Med Hyg 1999, 61:776-779.

16. Fry AE, Auburn S, Diakite M, Green A, Richardson A, Wilson J, Jallow M, Sisay-Joof $F$, Pinder M, Griffiths MJ, Peshu N, Williams TN, Marsh K, Molyneux ME, Taylor TE, Rockett KA, Kwiatkowski DP: Variation in the ICAM1 gene is not associated with severe malaria phenotypes. Genes Immun 2008, 9:462-469.

17. Rowe A, Obeiro J, Newbold Cl, Marsh K: Plasmodium falciparum rosetting is associated with malaria severity in Kenya. Infect Immun 1995, 63:2323-2326.

18. Rowe JA, Moulds JM, Newbold Cl, Miller LH: P. falciparum rosetting mediated by a parasite-variant erythrocyte membrane protein and complement-receptor 1. Nature 1997, 388:292-295.

19. Kun JFJ, Schmidt-Ott R, Lehman LG, Lell B, Luckner D, Greve $B$, Matousek P, Kremsner PG: Merozoite surface antigen 1 and 2 genotyping and rosetting of Plasmodium falciparum in severe versus mild malaria in Lambaréné, Gabon. Trans $R$ Soc Trop Med Hyg 1998, 92:110-114.

20. al Yaman F, Genton B, Mokela D, Raiko A, Kati S, Rogerson S, Reeder J, Alpers M: Human cerebral malaria: lack of significant association between erythrocyte rosetting and disease severity. Trans R Soc Trop Med Hyg 1995, 89:55-58.

21. Angkasekwinai $P$, Looareesuwan $S$, Chaiyaroj SC: Lack of significant association between rosette formation and parasitized erythrocyte adherence to purified CD36. Southeast Asian J Trop Med Public Health 1998, 29:41-45.

22. Cockburn IA, Mackinnon MJ, O'Donnell A, Allen SJ, Moulds JM, Baisor M, Bockarie M, Reeder JC, Rowe JA: A human complement receptor 1 polymorphism that reduces Plasmodium falciparum rosetting confers protection against severe malaria. Proc Natl Acad Sci U S A 2004, 101: 272-277.

23. Rowe JA, Handel IG, Thera MA, Deans AM, Lyke KE, Kone A, Diallo DA, Raza A, Kai O, Marsh K, Plowe CV, Doumbo OK, Moulds JM: Blood group $O$ protects against severe Plasmodium falciparum malaria through the mechanism of reduced rosetting. Proc Natl Acad Sci U S A 2007, 104: 17471-17476.

24. Patel SS, Mehlotra RK, Kastens W, Mgone CS, Kazura JW, Zimmerman PA: The association of the glycophorin $\mathrm{C}$ exon 3 deletion with ovalocytosis and malaria susceptibility in the Wosera, Papua New Guinea. Blood 2001, 98:3489-3491.

25. Maier AG, Duraisingh MT, Reeder JC, Patel SS, Kazura JW, Zimmerman PA, Cowman AF: Plasmodium falciparum erythrocyte invasion through glycophorin $C$ and selection for Gerbich negativity in human populations. Nat Med 2003, 9: 87-92.

26. Turner MW: Mannose-binding lectin: the pluripotent molecule of the innate immune system. Immunol Today 1996, 17: 532-540. 
27. Klabunde J, Berger J, Jensenius JC, Klinkert M, Zelck U, Kremsner PG, Kun JFJ: Schistosoma mansoni: Adhesion of mannan-binding lectin to surface glycoproteins of cercariae and adult worms. Exp Parasitol 2000, 95:231-239.

28. Garred $P$, Nielsen MA, Kurtzhals JA, Malhotra R, Madsen $\mathrm{HO}$, Goka BQ, Akanmori BD, Sim RB, Hviid L: Mannose-binding lectin is a disease modifier in clinical malaria and may function as opsonin for Plasmodium falciparum-infected erythrocytes. Infect Immun 2003, 71:5245-5253.

29. Luty AJF, Kun JFJ, Kremsner PG: Mannose-binding lectin plasma levels and gene polymorphisms in Plasmodium falciparum malaria. J Infect Dis 1998, 178:1221-1224.

30. Boldt AB, Luty A, Grobusch MP, Dietz K, Dzeing A, Kombila M, Kremsner PG, Kun JF: Association of a new mannose-binding lectin variant with severe malaria in Gabonese children. Genes Immun 2006, 7:393-400.

31. Boldt $A B$, Messias-Reason IJ, Lell $B$, Issifou $S$, Pedroso ML, Kremsner PG, Kun JF: Haplotype specific-sequencing reveals MBL2 association with asymptomatic Plasmodium falciparum infection. Malar $J$ 2009, 8:97.

32. Klabunde J, Uhlemann AC, Tebo AE, Kimmel J, Schwarz RT, Kremsner PG, Kun JF: Recognition of plasmodium falciparum proteins by mannan-binding lectin, a component of the human innate immune system. Parasitol Res 2002, 88: 113-117.

33. Bellamy R, Ruwende C, McAdam KPWJ, Thursz M, Sumiya M, Summerfield J, Gilbert SC, Corrah T, Kwiatkowski D, Whittle $\mathrm{HC}$, Hill AVS: Mannose binding protein deficiency is not associated with malaria, hepatitis B carriage nor tuberculosis in Africans. Q J Med 1998, 91:13-18.

34. Manolio TA, Collins FS: The HapMap and genome-wide association studies in diagnosis and therapy. Annu Rev Med 2009, 60:443-456.

35. Bellamy R, Beyers N, McAdam KP, Ruwende C, Gie R, Samaai P, Bester D, Meyer M, Corrah T, Collin M, Camidge DR, Wilkinson D, Hoal-Van Helden E, Whittle HC, Amos W, van Helden P, Hill AV: Genetic susceptibility to tuberculosis in Africans: a genome-wide scan. Proc Natl Acad Sci U S A 2000, 97:8005-8009.

36. Marquet S, Abel L, Hillaire D, Dessein H, Kalil J, Feingold J, Weissenbach J, Dessein AJ: Genetic localization of a locus controlling the intensity of infection by Schistosoma mansoni on chromosome 5q31-q33. Nat Genet 1996, 14: 181-184.

37. Fellay J, Shianna KV, Ge D, Colombo S, Ledergerber B, Weale M, Zhang K, Gumbs C, Castagna A, Cossarizza A, Cozzi-Lepri A, De Luca A, Easterbrook P, Francioli P, Mallal S, MartinezPicado J, Miro JM, Obel N, Smith JP, Wyniger J, Descombes P, Antonarakis SE, Letvin NL, McMichael AJ, Haynes BF, Telenti A, Goldstein DB: A whole-genome association study of major determinants for host control of HIV-1. Science 2007, 317:944-947.

38. Timmann $C$, Evans JA, König IR, Kleensang A, Rüschendorf $F$, Lenzen J, Sievertsen J, Becker C, Enuameh Y, Kwakye KO, Opoku E, Browne ENL, Ziegler A, Nürnberg P, Horstmann RD: Genome-wide linkage analysis of malaria infection intensity and mild disease. PLoS Genet 2007, 3:e48.

39. Jallow M, Teo YY, Small KS, Rockett KA, Deloukas P, Clark TG, Kivinen K, Bojang KA, Conway DJ, Pinder M, Sirugo G, SisayJoof F, Usen S, Auburn S, Bumpstead SJ, Campino S, Coffey A, Dunham A, Fry AE, Green A, Gwilliam R, Hunt SE, Inouye $M$, Jeffreys AE, Mendy A, Palotie A, Potter S, Ragoussis J, Rogers J, Rowlands K, et al.: Genome-wide and fine-resolution association analysis of malaria in West Africa. Nat Genet 2009; 24 May epub ahead of print.

40. Feuk $L$, Carson AR, Scherer SW: Structural variation in the human genome. Nat Rev Genet 2006, 7:85-97.

41. Lupski JR: Genomic disorders ten years on. Genome Med 2009, 1:42.

42. Kidd JM, Cooper GM, Donahue WF, Hayden HS, Sampas N, Graves T, Hansen N, Teague B, Alkan C, Antonacci F, Haugen E, Zerr T, Yamada NA, Tsang P, Newman TL, Tuzun E, Cheng Z, Ebling HM, Tusneem N, David R, Gillett W, Phelps KA,
Weaver M, Saranga D, Brand A, Tao W, Gustafson E McKernan K, Chen L, Malig M, et al.: Mapping and sequencing of structural variation from eight human genomes. Nature 2008, 453:56-64.

43. Redon $\mathrm{R}$, Ishikawa $\mathrm{S}$, Fitch $\mathrm{KR}$, Feuk L, Perry $\mathrm{GH}$, Andrews TD, Fiegler H, Shapero MH, Carson AR, Chen W, Cho EK, Dallaire S, Freeman JL, Gonzalez JR, Gratacos M, Huang J, Kalaitzopoulos D, Komura D, MacDonald JR, Marshall CR, Mei R, Montgomery L, Nishimura K, Okamura K, Shen F, Somerville MJ, Tchinda J, Valsesia A, Woodwark C, Yang F, et al.: Global variation in copy number in the human genome. Nature 2006, 444:444-454.

44. Omi K, Ohashi J, Patarapotikul J, Hananantachai H, Naka I, Looareesuwan S, Tokunaga K: Fcgamma receptor IIA and IIIB polymorphisms are associated with susceptibility to cerebral malaria. Parasitol Int 2002, 51:361-366.

45. Verra F, Mangano VD, Modiano D: Genetics of susceptibility to Plasmodium falciparum: from classical malaria resistance genes towards genome-wide association studies. Parasite Immunol 2009, 31:234-253.

46. Hill AV, Allsopp CE, Kwiatkowski D, Anstey NM, Twumasi P, Rowe PA, Bennett S, Brewster D, McMichael AJ, Greenwood BM: Common west African HLA antigens are associated with protection from severe malaria. Nature 1991, 352:595600.

47. Rao Y, Hoffmann E, Zia M, Bodin L, Zeman M, Sellers EM, Tyndale RF: Duplications and defects in the CYP2A6 gene: identification, genotyping, and in vivo effects on smoking. Mol Pharmacol 2000, 58:747-755.

48. Fukami T, Nakajima M, Yamanaka H, Fukushima Y, Mcleod HL, Yokoi T: A novel duplication type of CYP2A6 gene in African-American population. Drug Metab Dispos 2007, 35: 515-520.

49. Price RN, Uhlemann AC, van Vugt M, Brockman A, Hutagalung R, Nair S, Nash D, Singhasivanon P, Anderson TJ, Krishna S, White NJ, Nosten F: Molecular and pharmacological determinants of the therapeutic response to artemether-lumefantrine in multidrug-resistant Plasmodium falciparum malaria. Clin Infect Dis 2006, 42:1570-1577.

50. Uhlemann AC, McGready R, Ashley EA, Brockman A, Singhasivanon P, Krishna S, White NJ, Nosten F, Price RN: Intrahost selection of Plasmodium falciparum pfmdr1 alleles after antimalarial treatment on the northwestern border of Thailand. J Infect Dis 2007, 195:134-141.

51. Uhlemann AC, Krishna S: Antimalarial multi-drug resistance in Asia: mechanisms and assessment. Curr Top Microbiol Immunol 2005, 295:39-53.

52. Sidhu A, Uhlemann A, Valderramos S, Valderramos J, Krishna $S$, Fidock D: Decreasing pfmdr1 copy number in Plasmodium falciparum malaria heightens susceptibility to mefloquine, lumefantrine, halofantrine, quinine, and artemisinin. $J$ Infect Dis 2006, 194:528-535.

53. Kidgell C, Volkman SK, Daily J, Borevitz JO, Plouffe D, Zhou Y, Johnson JR, Le Roch K, Sarr O, Ndir O, Mboup S, Batalov S Wirth DF, Winzeler EA: A systematic map of genetic variation in Plasmodium falciparum. PLoS Pathog 2006, 2:e57

54. Nair S, Miller B, Barends $M$, Jaidee A, Patel J, Mayxay M, Newton P, Nosten F, Ferdig MT, Anderson TJC: Adaptive copy number evolution in malaria parasites. PLoS Genet 2008, 4: e1000243.

55. Foote SJ, Thompson JK, Cowman AF, Kemp DJ: Amplification of the multidrug resistance gene in some chloroquineresistant isolates of $\boldsymbol{P}$. falciparum. Cell 1989, 57:921-930.

56. Fidock DA, Nomura T, Talley AK, Cooper RA, Dzekunov SM, Ferdig MT, Ursos LM, Sidhu AB, Naude B, Deitsch KW, Su XZ, Wootton JC, Roepe PD, Wellems TE: Mutations in the $P$. falciparum digestive vacuole transmembrane protein PfCRT and evidence for their role in chloroquine resistance. $\mathrm{Mol}$ Cell 2000, 6:861-871.

57. Djimde A, Doumbo OK, Cortese JF, Kayentao K, Doumbo S, Diourte Y, Dicko A, Su XZ, Nomura T, Fidock DA, Wellems TE, Plowe CV, Coulibaly D: A molecular marker for chloroquine- 
resistant falciparum malaria. $N$ Engl J Med 2001, 344:257263.

58. Jiang H, Patel JJ, Yi M, Mu J, Ding J, Stephens R, Cooper RA, Ferdig MT, Su Xz: Genome-wide compensatory changes accompany drug- selected mutations in the Plasmodium falciparum gene. PLoS ONE 2008, 3:e2484.

59. Ribacke U, Mok BW, Wirta V, Normark J, Lundeberg J, Kironde F, Egwang TG, Nilsson P, Wahlgren M: Genome wide gene amplifications and deletions in Plasmodium falciparum. Mol Biochem Parasitol 2007, 155:33-44.

60. Winter G, Kawai S, Haeggstrom M, Kaneko O, von Euler A, Kawazu S, Palm D, Fernandez V, Wahlgren M: SURFIN is a polymorphic antigen expressed on Plasmodium falciparum merozoites and infected erythrocytes. J Exp Med 2005, 201:1853-1863.

61. Mphande F, Ribacke U, Kaneko O, Kironde F, Winter G, Wahlgren M: SURFIN4.1, a schizont-merozoite associated protein in the SURFIN family of Plasmodium falciparum. Malar J 2008, 7:116.

62. Noedl H, Se Y, Schaecher K, Smith BL, Socheat D, Fukuda MM: Evidence of artemisinin-resistant malaria in western Cambodia. N Engl J Med 2008, 359:2619-2620.

63. Dondorp AM, Nosten F, Yi P, Das D, Phyo AP, Tarning J, Lwin KM, Ariey F, Hanpithakpong W, Lee SJ, Ringwald P, Silamut K,
Imwong M, Chotivanich K, Lim P, Herdman T, An SS, Yeung S, Singhasivanon P, Day NPJ, Lindegardh N, Socheat D, White $\mathrm{NJ}$ : Artemisinin resistance in Plasmodium falciparum malaria. N Engl J Med 2009, 361:455-467.

64. Gupta K, Gupta RK, Hajela K: Disease associations of mannose-binding lectin \& potential of replacement therapy. Indian J Med Res 2008, 127:431-440.

65. Aksentijevich I, Masters SL, Ferguson PJ, Dancey P, Frenkel J, Royen-Kerkhoff A, Laxer R, Tedgard U, Cowen EW, Pham TH, Booty M, Estes JD, Sandler NG, Plass N, Stone DL, Turner ML, Hill S, Butman JA, Schneider R, Babyn P, El Shanti HI, Pope E, Barron K, Bing X, Laurence A, Lee CC, Chapelle D, Clarke GI Ohson $\mathrm{K}$, Nicholson $\mathrm{M}$, et al.: An autoinflammatory disease with deficiency of the interleukin-1-receptor antagonist. $N$ Engl J Med 2009, 360:2426-2437.

66. Fullwood MJ, Wei CL, Liu ET, Ruan Y: Next-generation DNA sequencing of paired-end tags (PET) for transcriptome and genome analyses. Genome Res 2009, 19:521-532.

Published: 02 September 2009

doi:10.1186/gm82

(c) 2009 BioMed Central Ltd 